\title{
Double vision: double trouble
}

\author{
Praveen Kesav, ${ }^{1}$ Valliappan Muthu, ${ }^{2}$ Dheeraj Khurana ${ }^{3}$
}

'Department of Neurology, VSM Hospital, Mavelikara, Kerala, India

${ }^{2}$ Department of Internal Medicine, Post Graduate Institute of Medical Education and Research, Chandigarh, India

${ }^{3}$ Department of Neurology, Post Graduate Institute of Medical Education and Research, Chandigarh, India

\section{Correspondence to} Dr Praveen Kesav,

drpraveenk464@gmail.com

Accepted 11 November 2014

\section{DESCRIPTION}

A 43-year-old smoker presented with painless binocular diplopia and numbness in the left frontotemporal region of 4 weeks duration. Physical examination revealed non-tender bony swelling in the left zygomaticotemporal region with posterior cervical lymphadenopathy and non-tender hepatomegaly (figure 1A, white arrow). Neurological examination revealed left superior oblique and lateral rectus palsy with sensory loss in the ophthalmic division of the left trigeminal nerve. A clinical diagnosis of left cavernous sinus syndrome was made. Gadolinium-enhanced MRI of the brain showed enhancing soft tissue mass in the left zygomaticotemporal region infiltrating the left cavernous sinus (figure 1B, arrowhead) and lateral rectus muscle (figure $1 \mathrm{~B}$, arrow). Contrast-enhanced CT of the chest and abdomen revealed a lesion in the middle lobe of the right lung suggestive of bronchogenic carcinoma (figure 1C) with mediastinal lymphadenopathy, and adrenal and liver metastases. Biopsy of the posterior cervical node revealed features suggestive of metastatic small cell carcinoma. Palliative chemoradiotherapy was initiated in view of an underlying diagnosis of stage IV small cell lung carcinoma. Metastases constitute the most common malignant tumour of the eyes in males, with the primary source being the lungs in the majority of cases. ${ }^{1}$ Orbital metastasis as the initial presentation of small cell lung carcinoma has been reported previously in the literature. ${ }^{2}{ }^{3}$ On the other hand, small cell lung carcinoma presenting with concomitant extracranial (temporal bone, lateral rectus muscle) and intracranial (cavernous sinus) involvement is extremely uncommon.
To cite: Kesav $P$, Muthu $V_{\text {, }}$ Khurana D. BMJ Case Rep Published online: [please include Day Month Year] doi:10.1136/bcr-2014207347

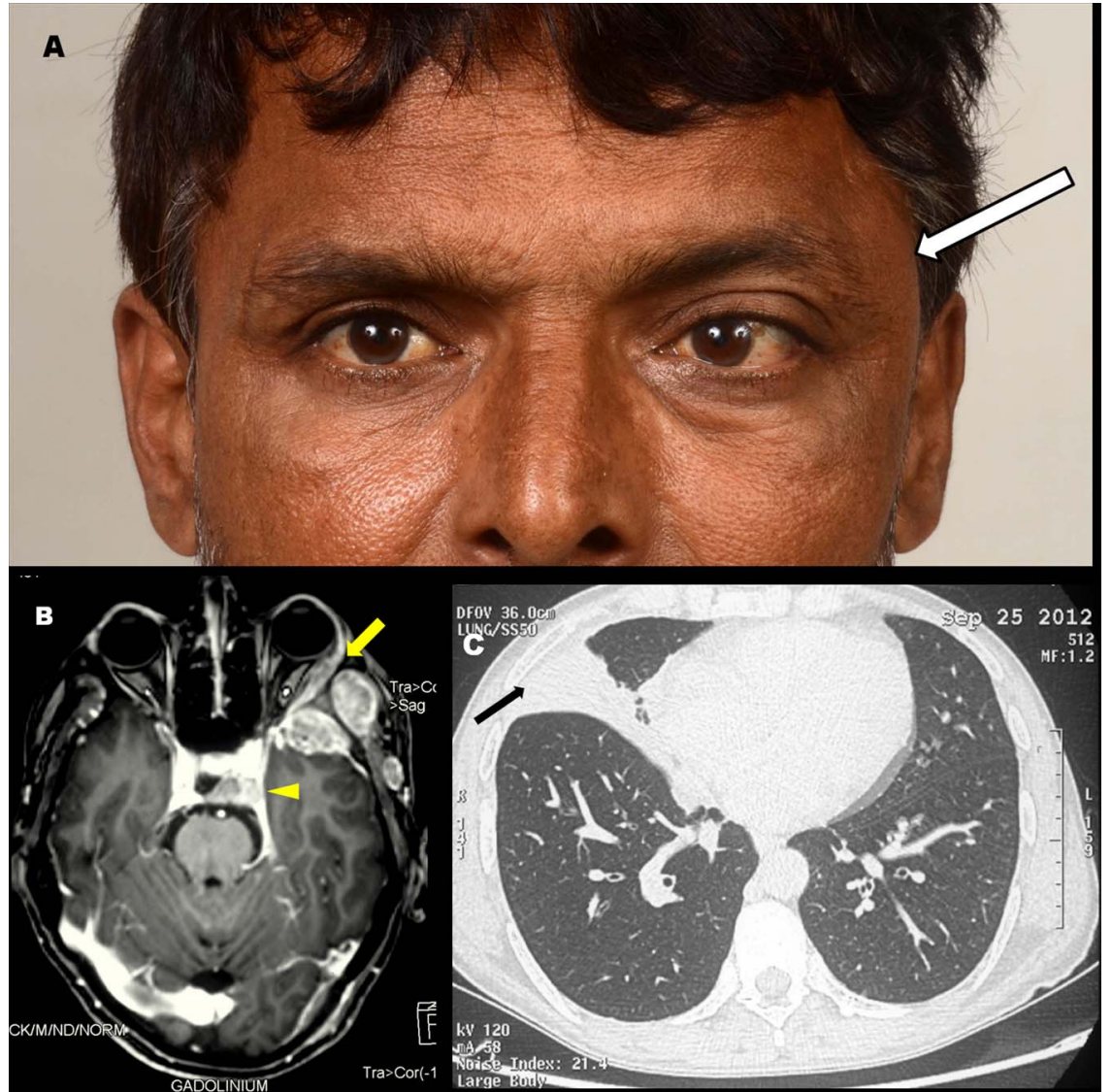

Figure 1 (A) Clinical photograph showing non-tender bony swelling in the left zygomaticotemporal region (arrow) with left superior oblique and lateral rectus palsy. (B) Cranial Gad MRI showing enhancing soft tissue mass in the left zygomaticotemporal region infiltrating the left cavernous sinus (arrowhead) and lateral rectus muscle (arrow). (C) CT of the chest revealing a homogenous lesion in the middle lobe of the right lung suggestive of bronchogenic carcinoma (arrow). 


\section{Learning points}

Metastases constitute the most common ocular malignancy.

- Small cell lung carcinoma is notorious for extrapulmonary manifestations.

- Concomitant intracranial and extracranial ocular pathology is most often secondary to infiltrative aetiopathogenesis.

Contributors PK was responsible for drafting the manuscript and reviewing the literature. VM was responsible for the data collection. DK was responsible for reviewing the manuscript.
Competing interests None.

Patient consent Obtained.

Provenance and peer review Not commissioned; externally peer reviewed.

\section{REFERENCES}

1 Buys R, Abramson DH, Kitchin FD, et al. Simultaneous ocular and orbital involvement from metastatic bronchogenic carcinoma. Ann Ophthalmol 1982;14:1165-71.

2 Shields JA, Shields CA, Brotman HK, et al. Cancer metastatic to the orbit: the 2000 Robert M. Curts lecture. Ophthal Plast Reconstr Surg 2001;17:346-54.

3 Mena AM, Pardo J. Orbital metastasis as the initial manifestation of small cell lung cancer. Acta Ophthalmol Scand 2002;80:113-15.

Copyright 2014 BMJ Publishing Group. All rights reserved. For permission to reuse any of this content visit

http://group.bmj.com/group/rights-licensing/permissions.

BMJ Case Report Fellows may re-use this article for personal use and teaching without any further permission.

Become a Fellow of BMJ Case Reports today and you can:

- Submit as many cases as you like

- Enjoy fast sympathetic peer review and rapid publication of accepted articles

- Access all the published articles

- Re-use any of the published material for personal use and teaching without further permission

For information on Institutional Fellowships contact consortiasales@bmjgroup.com

Visit casereports.bmj.com for more articles like this and to become a Fellow 